\title{
The boron isotope systematics of Icelandic basalts and melt inclusions
}

\author{
EDWARD W. MARSHALL ${ }^{1 *}$, SAEMUNDUR ARI \\ HALLDORSSON $^{1,2}$, EEMU RANTA $^{2}$, ALBERTO \\ CARACCIOLO $^{1}$, ENIKŐ BALI ${ }^{1}$, HEEJIN JEON ${ }^{3}$, MARTIN J. \\ WHITEHOUSE $^{3}$, ANDRI STEFANSSON ${ }^{1}$ \\ ${ }^{1}$ University of Iceland, Reykjavik, Iceland (*correspondence \\ edmarshall@hi.is) \\ ${ }^{2}$ NordVulk, Institute of Earth Sciences, University of Iceland \\ ${ }^{3}$ Swedish Museum of Natural History, Stockholm, Sweden
}

Boron isotope compositions $\left(\delta^{11} \mathrm{~B}\right)$ of ocean-island basalts (OIBs) place constraints on the cycling of volatile elements within Earth's interior. However, most OIB localities are underlain by altered oceanic crust that can contaminate OIB magmas and result in lava and melt inclusion $\delta^{11} \mathrm{~B}$ values that do not reflect the composition of the underlying mantle source. In contrast, Iceland is an OIB locality that is not underlain by altered oceanic crust and therefore it is unlikely that Icelandic magmas assimilate seawater-altered basalt.

Previous studies of Icelandic basalts focused on only a few localities $(n=4)$ and were unable to conclusively link variations in $\delta^{11} \mathrm{~B}$ to mantle heterogeneity. Here, we present new high precision (2SE @ 1 ppm B = 1.6\%) SIMS $\delta^{11} \mathrm{~B}$ values and boron concentrations from well characterized subglacial basaltic glasses $(\mathrm{n}=40)$ and olivine and plagioclase hosted melt inclusions $(n=15)$. These samples comprehensively span the known geochemical and spatial variability of Icelandic basalts.

$\delta^{11} \mathrm{~B}$ values of subglacial Icelandic basalts range from -9.2 to $-1.0 \%$ and melt inclusion $\delta^{11} \mathrm{~B}$ values range from -11.6 to $-3.7 \%$. The population of subglacial glasses has higher $\delta^{11} \mathrm{~B}$ values than MORB, whereas the melt inclusion population has similar $\delta^{11} \mathrm{~B}$ values to MORB [1]. Indices of mantle heterogeneity and degree of partial melting such as $\mathrm{Zr} / \mathrm{Nb}$ and $\mathrm{La} / \mathrm{Sm}$ correlate with $\delta^{11} \mathrm{~B}$ values in the subglacial glass and melt inclusion suite.

Low $\mathrm{La} / \mathrm{Sm}$ glasses have $\delta^{11} \mathrm{~B}$ values similar to MORB ( -7\%), whereas high La/Sm glasses have $\delta^{11} \mathrm{~B}$ values higher than MORB $(\sim-3 \%)$ suggesting that boron isotope compositions are controlled by processes and lithologies within the Icelandic mantle source. This correlation highlights the juxtaposition of DMM and recycled materials in the mantle source of Iceland. Additionally, this correlation persists despite assimilation of Icelandic crust (evident through low $\delta^{18} \mathrm{O}$ values in the glasses). Because assimilation of volatile-rich B-bearing altered lavas would rapidly overprint primitive basalts, assimilants within the Icelandic crust must be B depleted. [1] Marschall, H.R., et al. (2017) Geochim. et Cosmochim. Acta, v. 207, p. 102-138 